\title{
Role of Fibrin Glue in Management of Perianal Fistula in Assiut University Hospital
}

\author{
TAREK A. MOSTAFA, M.D.; MOSTAFA A. ABD AZIZ, M.D.; AHMED M. ALI, M.D. and \\ MOHAMED B. NOAMAN, M.Sc.
}

The Department of General Surgery, Faculty of Medicine, Assiut University, Assiut, Egypt

\begin{abstract}
Background: A fistula-in-ano is an abnormal hollow tract or cavity that is lined with granulation tissue and that connects a primary opening inside the anal canal to a secondary opening in the perianal skin; secondary tracts may be multiple and can extend from the same primary opening.

Patients and Methods: In our study we had 40 patients who were complainingof fistula in ano (high and low perianal fistula). They were evaluated in the post-operative period for the complications as recurence, sphincteric disturbance, postoperative abscess and post-operative pain from June 2016 till May 2017 in the General Surgery Department in Assiut University Hospital.

Results: After injection of 40 cases of perianal fistula it was found that 5 cases out of 16 cases of high perianal fistula $(31.2 \%)$ developed recurrence of their fistulas tract, while 11 cases did not develop recurrence $(69.8 \%)$ after 6 moths follow-up. On the other hand 5 cases of low perianal fistula out of 24 cases $(20.8 \%)$ developed recurrence of their fistulas with 19 cases $(79.2 \%)$ that did not develop recurrence their fistulous tract after 6 months follow-up. Other complication noticed in this study was post-operative abscess and reported in 3 cases only $(7.5 \%)$. There was no post-operative incontinence or post-operative pain or bleeding reported in this study.

Conclusion: Injection of fibrin glue in aperianal fistula is simple, easy and safe technique with lower rate of complication as loss of sphincteric function, post-operative pain, intra operative bleeding and post-operative wound infection. This technique can be repeated even at the out patient clinic.
\end{abstract}

Key Words: Fibrin glue - Perianal fistula.

\section{Introduction}

A FISTULA-IN-ANO is an abnormal hollow tract or cavity that is lined with granulation tissue that connects a primary opening inside the anal canal to a secondary opening in the perianal skin. Secondary tracts may be multiple and can extend from the same primary opening.

Correspondence to: Dr. Mohamed B. Noaman, E-Mail: mohamed badre7490@Gmail.com
Most fistulas are thought to arise as a result of cryptoglandular infection with aresultant perirectal abscess the abscess represents the acute inflammatory event, whereas the fistula is representative of the chronic process. Symptoms generally affect quality of life significantly, and they range from minor discomfort and drainage with resultant hygienic problems of sepsis.

Historical references indicate that Louis XIV of France was treated for an anal fistula in the 18 th century. Salmon established a hospital in London (St. Mark's) devoted to the treatment of fistula-inano and other rectal conditions [1].

In the late 19 th and early 20 th centuries, prominent surgeons, such as Goodsall and Miles, Milligan and Morgan, Thompson, and LockhartMummery, made substantial contributions to the treatment of anal fistula. These surgeons offered theories on pathogenesis and classification systems for fistula-in-ano [2] . Treatment of fistula-in-ano remains challenging [3]. No definitive medical therapy is available for this condition, though longterm antibiotic prophylaxis and infliximab may have a role in recurrent fistulas in patients with Crohn disease. Surgery is the treatment of choice, with the goals of draining infection, eradicating the fistulous tract, and avoiding persistent or recurrent disease while preserving the sphincteric functions [4].

\section{Patients and Methods}

Across sectional study included 40 patients with perianal fistula (high and low) after getting their consent to be treated at Assiut University Hospital.

Duration of the study: 12 months from June 2016 to May 2017. 
Out come of the study:

1- Primary out come: Is to asses role of fibrin glue in decreasing recurrence rate of perianal fistula.

2- Secondary out come: Is to asses role of fibrin glue in decreasing post-operative pain and disturbed sphincteric function.

\section{Exclusion criteria:}

HIV positive patient, patients with rectovaginal fistula, fistulas with chronic cavities and acute sepsis and patients were not willing undergo this type of treatment.

\section{Inclusion criteria:}

All patients with perianal fistula (high and low) were in the age group between 20 to 60 years old.

History is taken from the patients as regards age, complaint and if the perianal fistula is recurrent or denovo.

Then all patients are inspected per rectally looking for the external opening and examined per rectally looking for the internal opening which was palpated as pitting or induration then the tract can be assessed whether it extend above or below ano rectal ring. Per rectal examination with anoscopy or digital examination can detect all low perianal fistulas (where the internal opening lied below the ano rectal ring).

Diagnosis of high perianal fistula (internal opening above ano rectal ring) required fistulogram [5] in which the dye enhanced the internal opening and appeared in the rectum. It is also helpful in detection of any cavities and number of tracts.

MRI could be done in only few patients because of high cost and poor affordability. MRI helpful in detection high perianal fistula and number of tracts [6].

\section{Pre-operative antibiotic:}

This has been used both to eradicate perineal sepsis, which is associated with recurrence in the conventional treatment of fistulae [7] and because certain bacterial species seem capable of lysing fibrin seal in vitro [8]. Antibiotics have been administered either pre-operatively, intra-operatively and/or post-operatively, and either parenteraly, enterally, locally to the fistula tract.

Under spinal anesthesia with the patient in the lithotomy position external and internal opening of the perianal tract were identified.
The fistulous tract is curetted and irrigated with normal saline. All investigators performed mechanical cleansing of the tract. Some also performed chemical cleansing with hydrogen peroxide, this may be important as antibiotics fail to prevent abscess formation secondary to bacteria trapped in fibrin clots [9].

Befor instillation of the fibrin glue the internal opening of perianal tract must be closed.

Closure of the internal opening seems a sensible part of treatment. It not only prevents fibrin glue from migrating out of the fistula tract into the anal canal or rectum, but also allows the glue to be inserted under some pressure to fill any secondary tracts. Methods of occlusion of the internal opening include digital compression whilst instilling the glue [6], covering the opening with vaseline gauze and simple stitch closure.

\section{Instillation of fibrin glue:}

Necessarily, there is uniformity in description of glue instillation. After identification of both the internal and external openings, and tract cleansing the glue is instilled.

The individual components are mixed and warmed, then drawn up into two syringes (syringe 1: Fibrinogen, factor XIII, aprotinin, and fibronectin; syringe 2: Thrombin and calcium chloride solution), which are subsequently placed in a twosyringe clip, which shares a common plunger.

A plastic double-lumen-Y-connector joins the two syringes. The trunk of the $\mathrm{Y}$-shaped connector is then connected to a single lumen catheter, which is inserted into the tract, and if the internal opening has been left open, until the tip can be seen at the internal opening.

On injection, the components mix at the tip of the catheter to form fibrin glue. Slow withdrawal of the catheter at instillation is performed and visualization of the glue should occur, if the internal opening is patent at this opening, and in all cases at the external opening.

Once the glue is set the procedure is complete; it takes 3-5 minets for the fibrin glue to adhere firmly to the surrounding tissue and $10 \mathrm{~min}$ to reach $70 \%$ of its maximum strength (full strength occurs after 2 hours).

Post-operative dietary restrictions and antibiotic:

Pre-operative mechanical bowel preparation and post-operative diets restricted to liquid intake for 24-48h [6] have been used to avoid early bowel 
movement, minimize anal canal disturbance, and thus avoid early fibrin plug extrusion. The patients must be on oral antibiotic for five days.

\section{Follow-up:}

The patients were followed-up in the postoperative period at the first week, at the first month, at three months and at six moths done in the out patient clinic.

The data were analyzed using SPSS statstical soft ware. Quantitative values with normal distribution expressed as mean \pm SD deviation. Qualitative values expressed as percentage of total number of cases. The student $t$-test and Chi-square testwere used in the analysisof the statistical differences, $p$-values $\leq 0.05$ was accepted as significant.

\section{Results}

Age group:

It was found also that 12 cases $(30 \%)$ were in the age group between. 20-40 years and 28 cases $(70 \%)$ were in the age group between $40-60$ years.

\section{Post-operative complication:}

After injection of 40 cases of perianal fistula it was found that 5 cases out of 16 cases of high perianal fistula (31.2\%) developed recurrence of their fistulas tract while 11 cases did not develop recurrence $(69.8 \%)$ after 6 moths follow-up.

On the other side 5 cases of low perianal fistula out of 24 cases (20.8\%) develop recurrence of their fistulas with 19 cases (79.2\%)were not develop their fistulas tract after 6 months follow-up.

Another complication noticed in this study was post-operative abscess reported in 3 cases only (7.5\%). There was no post-operative incontinence or post-operative pain or bleeding reported in this study.

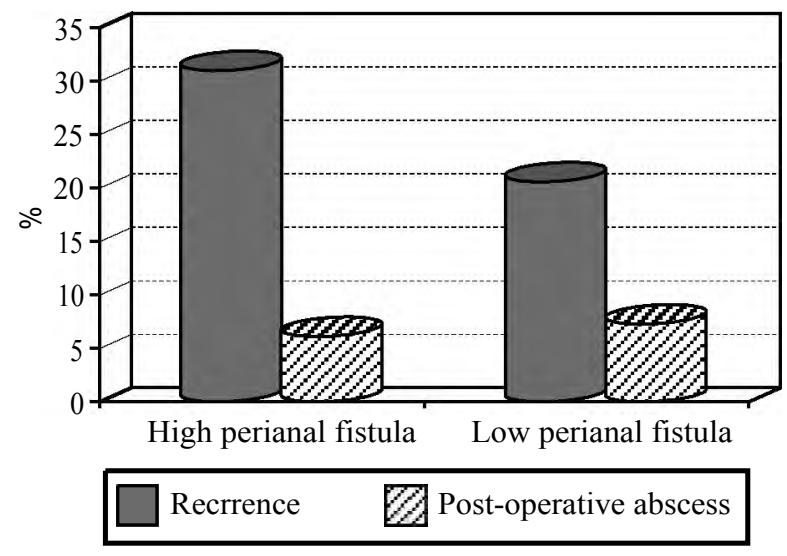

Fig. (1): Complication cases relationship.
Table (1): Age group-cases number relationship.

\begin{tabular}{lcc}
\hline Parameter & Number of cases & Percentage $(\%)$ \\
\hline $20-40$ years & 12 cases & 30 \\
40-60 years & 28 cases & 70 \\
\hline
\end{tabular}

Table (2): Post-operative complication-cases number relationship.

\begin{tabular}{lll}
\hline Parameter & Number of cases & Percentage (\%) \\
\hline Recurrence: & & 31.2 \\
High perianal fistula & 5 cases & 20.8 \\
Low perianal fistula & 5 cases & \\
Post-operative abscess: & & 6.2 \\
High perianal fistula & 1 case & 8.3 \\
Low peianal fistula & 2 cases & 0 \\
Incontinence: & No cases & 0 \\
Post-operative pain & No cases & 0 \\
Post-operative bleeding & No cases & \\
\hline
\end{tabular}

\section{Discussion}

Management of anal fistulas is notoriously one of the most difficult problems to deal with in coloproctological surgery [12]. Traditional treatments, including the use of cutting setons and advancement flap repairs, have been shown to be effective in promoting fistula healing. However, these methods have also been related to significant rates of sphincter impairment and anal incontinence.

Over the last 2 decades, fibrin glue injection has been investigated as a potential first-line therapy for anal fistula. This treatment modality is appealing because it carries no risk of incontinence associated with division of sphincter muscles. It is safe and easy to perform, avoids open perineal wounds, and does not interfere with future surgical treatments if necessary [11]. The efficacy of the fibrin glue injection, however, remains in question. While some authors have reported healing rates as high as $85 \%$, others failed to obtain any long-term healing $(0 \%)$ using the technique [13]. These discrepant results are likely due to differences in complexity and etiology of the fistulas included in each series. There are also significant variations in the length of post-operative follow-up among the published reports.

In the present study, we tried to exclusively address the efficacy of the fibrin glue treatment in patients with anal fistulas of cryptoglandular origin and fistula due to Chron's disease in addition to recurrent cases after failure of other surgical techniqes. These specific inclusion criteria may, in part, explain the low success rate $(69-80 \%)$ that we obtained with the fibrin glue treatment, since 
our surgical technique does not differ from techniques used by other authors [12]

In contrast, other authors have achieved higher rates of success in treatment of cryptoglandular fistulas [13]. In the largest published series to date, Cintron et al., [10]. Reported a healing rate for cryptoglandular fistulas of $63 \%$, compared with $35 \%$ for fistulas of other etiologies, with a mean follow-up of 1 year. Although no study has been able to demonstrate a statistically significant difference in healing rates according to fistula etiology [14]. It is generally agreed that anal fistulas associated with Crohn's diseases more liable for recurrence.

In our study 40 patients were included with 16 cases with high perianal fistula and 24 cases with low perianal fistula most of them of cryptoglandular in origin (36 cases) and Chron's disease (4 cases).

In our series $25 \%$ of the fistula recurrences were observed within 6 months of treatment. None of our patients presented a fistula recurrence after 6 months of follow-up. Fibrin glue injection proved to be a very safe treatment. As in previous published studies, there were no treatment-related complications in our study or adverse effects on subsequent treatments.

In this series, fibrin glue treatment for cryptoglandular anal fistulas achieved a sucscess rate ranging from (69\% in high cases and $80 \%$ in low cases). This result calls into question the use of fibrin glue as a first-line treatment for these patients. Several unfavorable aspects have to be taken into account when other method is chosen, including monetary costs, health resources, potential anesthetic risks, surgeon's time, time off from work and need for at least 1-year of postoperative followup. Therefore, it seems justifiable to use fibrin glue as routine first surgical approach for complex anal fistulas at this time.

However, because this treatment is safe and does not compromise future surgical treatments [11]. It might exceptionally have a limited role in selected very complex cases in which sphincter impairment is highly anticipated. In this situation, patients should be clearly warned about success rate expected with the procedure and the potential need of subsequent treatments.

At this time there is no consensus in the literature about the efficacy of fibrin glue injection in the treatment of cryptoglandular anal fistulas.

\section{Conflicts of interest:}

No conflict of interest has been declared.

\section{References}

1- CORMAN M.L.: Anal Fistula. Colon \& Rectal Surgery. 5th ed. Philadelphia, Pa: Lippincott Williams \& Wilkins, Chapter 11, 2005.

2- BELLIVEAU P.: Anal fistula. Current Therapy in Colon and Rectal Surgery. Philadelphia: BC Decker, 22-7, 1990.

3- PHILLIPS J., LEES N. and ARNALL F.: Current management of fistula-in-ano. Br. J. Hosp. Med. (Lond), Mar. 76 (3): 142, 144-7, 2015.

4- VASILEVSKY C.A. and GORDON P.H.: Benign Anorectal: Abscess and Fistula. Wolff B.G., Fleshman J.W., Beck D.E., Pemberton J.H., Wexner S.D., eds. The ASCRS Textbook of Colon and Rectal Surgery. New York, NY: Springer, Chapter 13, 2007.

5- HJORTRUP A., MOESGAARD F. and KJAERGÅRD J.: Fibrin adhesive in the treatment of perineal fistulae. Dis. Colon. Rectum., 34: 752-4, 1991.

6- PATRLJ L., KOCMAN B., MARTINAC M., JADRIJEVIC S., SOSA T., SEBECIC B. and BRKLJACIC B.: Fibrin glue-antibiotic mixture in the treatment of anal fistulae: Experience with 69 cases. Digestive Surg., 17: 77-80, 2000.

7- GARCIA-AGUILAR J., BELMONTE C., WONG D.W., GOLDBERG S.M. and MADOFF R.D.: Cutting seton versus two-stage seton fistulotomy in the surgical management of high anal fistulae. Br. J. Surg., 85: 243-5, 1998.

8- HOFFMAN S. and MOESGAARD F.: Bacterial lysis of fibrin seal in vitro. Eur. Surg. Res., 20: 75-81, 1988.

9- KRAM H. and BANSAL M.: Antibacterial effects of fibrin glue-antibiotic mixtures. J. Surg. Res., 50: 175-8, 1992.

10- CINTRON J.R., PARK J.J., ORSAY C.P., PEARL R.K., NELSON R.L. and ABCARIAN H.: Repair of fistulasin-ano using autologous fibrin tissue adhesive. Dis. Colon. Rectum., 42: 607-13, 1999.

11- LOPES-PAULO F.: O Emprego Da Cola De Fibrina No Tratamento Das Fístulas Anais. Rev. Bras. Coloproctol., 26: 868, 2006.

12- MIZRAHI N., WEXNER S.D., ZMORA O., Da SILVA G., EFRON J., WEISS E.G., VERNAVA A.M. $3^{\text {rd }}$ and NOGUERAS J.J.: Endorectal advancement flap: Are there predictors of failure? Dis. Colon. Rectum., 45: 1616-2, 2002.

13- SENTOVICH S.M.: Fibrin glue for all anal fistulas. J. Gastrointest. Surg., 5: 158-61, 2001.

14- SWINSCOE M.T., VENTAKASUBRAMANIAM D.G. and JAYNE D.G.: Fibrin glue for fistula-in-ano: The evidence reviewed. Tech. Coloproctol., 9: 89-94, 2005. 


\section{دورغراء الفيبرين فى علاج الناسور الشرجى}

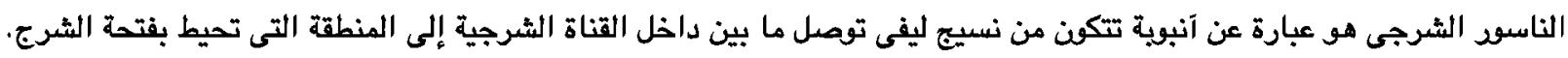

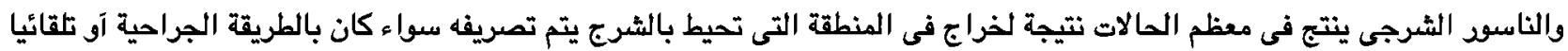

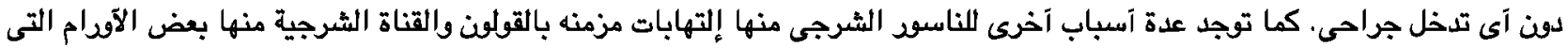

تصيب المستقيم العلاج الكيماوى والإثشعاعى وغيرها.

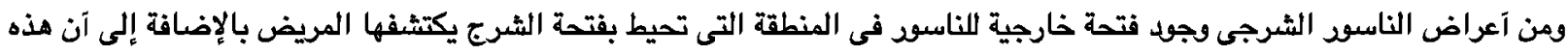

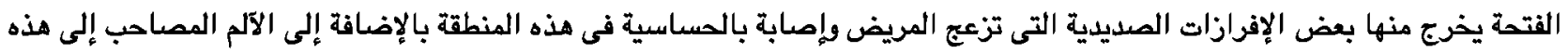

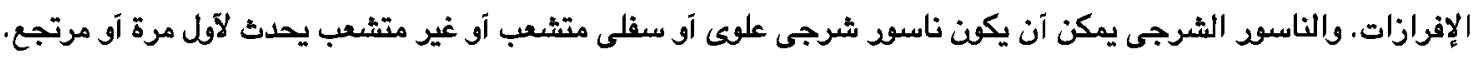

ويتم تثخيص الناسود الشُرجى عن طريق الفحص الإكلينيكى وعن طريق بعض الفحوصات التى تجرى للمريض. فعن طريق الفحص

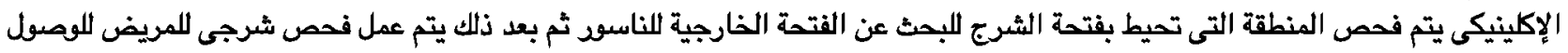

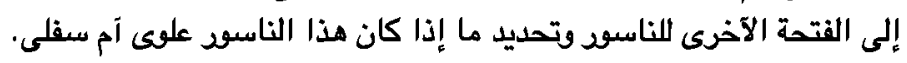

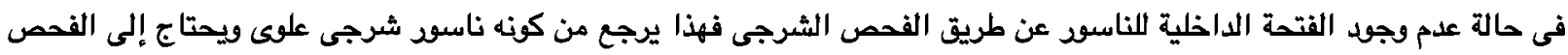

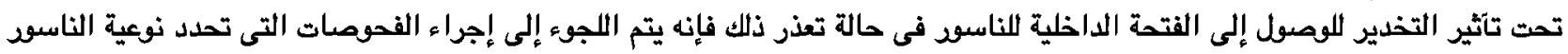

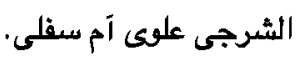

من أمثلة هذه الفحوصات إجراء آشُعة بالصبغة على الناسود الشرجى حيث يتم حقن صبغة في الفتحة الخارجية للناسود ومتابعة خروجها

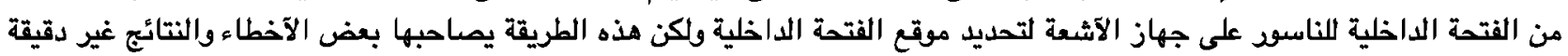
بنسبة عالية.

ولذالك فإن آشعة الرنين المفناطيسى على الناسود الشرجى هى الآمثل لتحديد ما إذا كان هذا الناسود علوى آم سفلى متشعب آم لا ولكن

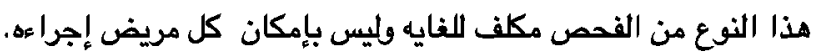

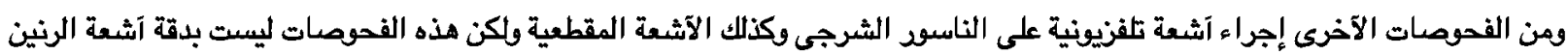

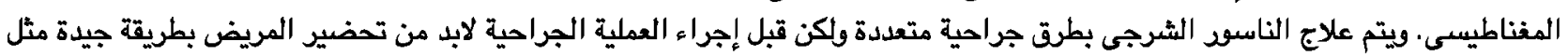

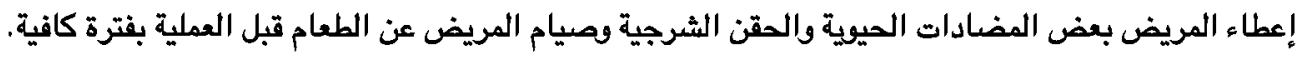

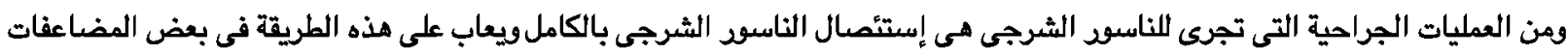

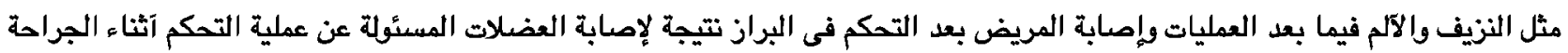
بالإضافة إلى إحتمالية رجوع الناسور الشرجى مرة آخرى. ومن الطرق الآخرى التى تستخدم فى العلاج طريقة السيتون وطريقة ترقيع الناسود الشرجى عن طريق غلق الفتحة الداخلية للناسود بنسيج من داخل القناة الشرجية والمستقيم وغيرها.

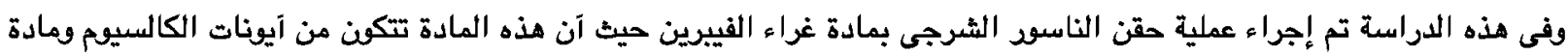

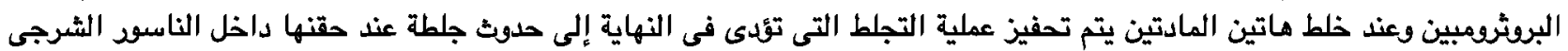
وهذه الجلطة تقوم بعمل نسيج ليفى وهو بدوده يقوم بغلق الناسور الشرجى.

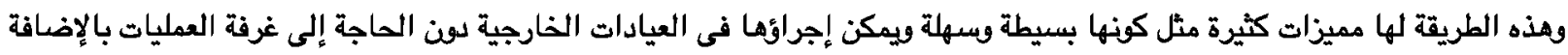

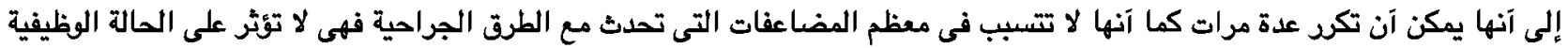

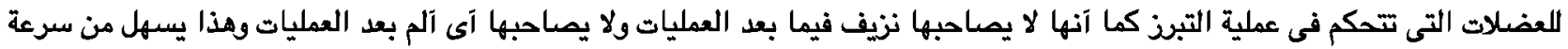
خرىج المريض من المستشفى وسيرعة عولته إلى الى آعمالة اليومية. 